\title{
Landscape Coefficients for Single- and Mixed-species Landscapes
}

\author{
Tim R. Pannkuk ${ }^{1}$ \\ Department of Agricultural Sciences, Sam Houston State University, P.O. \\ Box 2088, Huntsville, TX 77340
}

\author{
Richard H. White \\ Department of Soil and Crop Sciences, Texas A\&M University, College \\ Station, TX 77843-2474
}

\section{Kurt Steinke \\ Department of Crop and Soil Sciences, Michigan State University, East Lansing, MI 48824}

\section{Jacqueline A. Aitkenhead-Peterson, David R. Chalmers, and James C. Thomas \\ Department of Soil and Crop Sciences, Texas A\&M University, College Station, TX 77843-2474}

Additional index words. evapotranspiration, Stenotaphrum secundatum, Quercus shumardii, landscape coefficient, turf

\begin{abstract}
Urban landscape irrigation is becoming increasingly important from a resource management point of view. Significant water use savings may be achieved if landscape irrigation is based on reference evapotranspiration $\left(\right.$ ET $\left._{0}\right)$. This study measured landscape crop coefficients $\left(K_{L}\right)$ for landscapes that are comprised of different vegetation types and irrigation water quality differences affecting $K_{L}$. The $K_{L}$ was determined from the ratio of actual evapotranspiration to the $\mathbf{E T}_{0}$ calculated from the modified PenmanMonteith equation. Irrigation quantity was based on $100 \%$ replacement of $\mathbf{E T}_{0}$. The $\mathrm{K}_{\mathrm{L}}$ values were determined for the following landscape vegetation on a fine sandy loam: St. Augustinegrass [Stenotaphrum secundatum (Walt.) Kuntze.], a single shumard red oak (Quercus shumardii Buckl.), St. Augustinegrass plus red oak, native grasses [Muhlenbergia capillaries (Lam.) Trin. and Schizachyrium scoparium (Michx.) Nash], and native grasses plus Red Oak in both College Station (CS) and San Antonio (SA), TX. Soil was systematically placed into lysimeters containing a drainage system and soil moisture probes. Lysimeters $(1136 \mathrm{~L})$ were placed in-ground in a randomized complete block design with three blocks. Soil moisture measurements were made at 0 - to 20-, 20- to 40-, and 40 - to $60-\mathrm{cm}$ depths. The $K_{\mathrm{L}}$ was determined after a rainfall or irrigation event for periods of 2 to 5 days. During the combined growing seasons of 2007 and 2008, $K_{L}$ in $S A$ increased from early, to mid, to late season. In CS, the $K_{L}$ was unaffected by plant treatment or season. The $\mathrm{St}$. Augustinegrass treatment $\mathrm{K}_{\mathrm{L}}$ seasonally ranged from 0.45 to 0.62 in SA. In CS, soil sodium accumulation caused decreased $K_{L}$. These results of $K_{L}$ for mixed-species landscapes on non-sodic sites trend toward seasonal values of 0.5 to 0.7 for irrigation decisions in southern Texas. Landscape coefficients can be used as a tool in irrigation decision-making, which could contribute to water savings in amenity landscapes.
\end{abstract}

Water is one of our most valuable natural resources and water conservation continues to be a major national priority [Vickers, 2001; Texas Water Development Board (TWDB), 2007]. As a result of population growth, current potable water supplies will be insufficient by the year 2050 in Texas (TWDB, 2003). Currently, 7.8 billion gallons, or $\approx 30 \%$ of all potable water, is used outdoors (U.S. Geologic Survey, 2006) primarily for landscape irrigation (Kjelgren et al., 2000; Vickers, 2001; White et al., 2004).

Received for publication 9 Aug. 2010. Accepted for publication 9 Aug. 2010.

${ }^{1}$ To whom reprint requests should be addressed; e-mailpannkuk@shsu.edu.
Landscape plants provide an aesthetic appeal to urban landscapes, prevent erosion of the soil that impairs surface water supplies, sequester carbon, add oxygen to the atmosphere, and improve recharge of groundwater (Beard and Green, 1994). Irrigated areas within the built landscape can also increase property values. Yet, end-user lack of understanding of best management practices for landscape water management will routinely contribute to excess water use. In a study of 800 home consumers in College Station, TX, it was estimated that more than 24 to 34 million gallons of excess water, that is water in excess of an irrigation coefficient of 1.0 of the yearly reference evapotranspiration, were used annually for landscape irrigation during 2001 through 2003 (White et al., 2004).
Appropriate landscape design and planning has been heralded for decades as a step toward water conservation (Welsh et al., 2000), yet water consumer irrigation practices have not changed with landscapes designed for water conservation (Peterson et al., 1999).

Evapotranspiration (ET) is the amount of water lost through evaporation from the soil and plant surface plus that lost through plant transpiration. Reference evapotranspiration $\left(\mathrm{ET}_{\mathrm{o}}\right)$ water loss rate is based on environmental demands for a cool-season turf completely covering the ground. Landscape irrigation based on $\mathrm{ET}_{\mathrm{o}}$ is an emerging area of water conservation that links plant water use to irrigation water replacement rates and schedules. There is evidence that $\mathrm{ET}_{\mathrm{o}}$ weather station data can be used in irrigating landscape plants (Shaw and Pittenger, 2004; White et al., 2004), yet there is a lack of information on the fundamental seasonal relationships between $\mathrm{ET}_{\mathrm{o}}$ and actual evapotranspiration of turfgrasses, native grass species, tree species, and mixed species landscapes under different climates. An understanding of this relationship is critical to providing accurate recommendations for landscape irrigation based on $\mathrm{ET}_{\mathrm{o}}$.

A variety of state-of-the-art technologies are available for reducing irrigation water use in amenity landscapes. One of these "smart irrigation" technologies is an ET-based controller. McCready et al. (2009) compared the effectiveness of an ET-based controller technology treatment with a time-based system with $2 \mathrm{~d}$ of irrigation per week without any type of sensing mechanism. Compared with the time-based system, the ET-based treatments used $25 \%$ to $62 \%$ less water without compromising turf quality. This demonstrates the benefit of using ET-based controllers in landscape irrigation, but there is a gap in the knowledge of what fraction (e.g., 0.7, 0.8) of the $\mathrm{ET}_{\mathrm{O}}$ is needed in the mixed-species landscape. Coupling ET-based plant water use with ET-based irrigation controllers can provide a means of accurately applying water to the landscape.

It is well documented that sodic and saline soil conditions can alter soil water use and transpiration in landscape plant materials (Eom et al., 2007; Munn, 2002; Wang and Nii, 2000). Dean et al. (1996) demonstrated a differential response in bermudagrass and tall fescue growth in arid climates where excess salt and water-induced stress were factors. The Dean et al. study also demonstrated that both grasses could be grown with moderately saline water if irrigation water volume was above a species-specific threshold value. Carrow and Duncan (1998) documented how excess soil sodium $(\mathrm{Na})$ levels can lead to soil structural deterioration and to specific ion toxicity in shoot and root tissue. Sodic soil conditions may develop in amenity landscapes if high $\mathrm{Na}$ irrigation water is used. Therefore, the actual ET/ $\mathrm{ET}_{\mathrm{O}}$ relationship of plants may vary between sodic landscape sites and non-sodic landscape sites. As sources of potable fresh water are depleted, lowerquality water increasingly becomes used for irrigation of turf and woody plants. 
The objectives of this study were to 1) compare landscape crop coefficients $\left(\mathrm{K}_{\mathrm{L}}\right.$; actual ET to $\mathrm{ET}_{\mathrm{o}}$ ) by landscape plant treatment; and 2) determine if seasonal differences in $\mathrm{K}_{\mathrm{L}}$ occur within sites.

\section{Materials and Methods}

Site description. The experiment was conducted at two sites: the Texas A\&M University Turfgrass Field Laboratory in College Station, TX, and at a site adjacent to the San Antonio Water System Leon Creek Waste Water Treatment Facility in San Antonio, TX. These two sites will be referred to as the College Station (CS) region and the San Antonio (SA) region. College Station on average has $1000 \mathrm{~mm}$ rainfall, $47.8 \%$ humidity, and an $\mathrm{ET}_{\mathrm{o}}$ of $1430 \mathrm{~mm}$. San Antonio on average has $764 \mathrm{~mm}$ rainfall, $42.9 \%$ humidity, and an $\mathrm{ET}_{\mathrm{o}}$ of $1522 \mathrm{~mm}$. Table 1 presents average seasonal rainfall and actual seasonal rainfall by site.

Irrigation water analysis. Irrigation water for each site was from the local potable water supply. Irrigation water samples from both sites were analyzed in July 2008. The pH, calcium $(\mathrm{Ca})$, magnesium $(\mathrm{Mg}), \mathrm{HCO}_{3}, \mathrm{Na}$, and sodium adsorption ratio (SAR) were 9.1, $2,0.5,393,232$, and 38 , respectively, for irrigation water at $\mathrm{CS}$ versus 7.9, 24, 16, 190, 12 , and 0.5 for irrigation water in SA. Electrical conductivity of irrigation water was 0.089 and $0.057 \mathrm{~S} \cdot \mathrm{m}^{-1}$ in CS and SA, respectively.

Lysimeter construction and sensing. Individual waterproof lysimeter containers were 1136-L oval stock tanks (R.G. Applegate Steel Co., Saratoga, IN) $2.43 \mathrm{~m}$ long $\times$ $1.02 \mathrm{~m}$ wide $\times 0.68 \mathrm{~m}$ deep. The distance between the individual lysimeters was 30.5 $\mathrm{cm}$. Tank bottoms were constructed from 1.0 $\mathrm{mm}$ galvanized steel and sides were made from $0.85 \mathrm{~mm}$ galvanized steel. Tanks were placed in-ground on a smooth level surface such that the tank tops were $5 \mathrm{~cm}$ beneath the surface grade. The bottom of each tank was filled to a depth of $5.1 \mathrm{~cm}$ with $1-\mathrm{cm}$ diameter gravel. A chlorinated polyvinyl chloride (CPVC) leachate pipe system was embedded in this gravel layer to allow leachate removal

Table 1. Average seasonal rainfall, actual seasonal rainfall, and percent variation from average rainfall during 2007 and 2008 in College Station and San Antonio, TX.

\begin{tabular}{lccc}
\hline \multicolumn{4}{c}{ College Station } \\
\hline Season & Avg (mm) & 2007 & 2008 \\
\hline Early & 248 & $223(10 \%)$ & $181(25 \%)$ \\
Mid & 270 & $311(+15 \%)$ & $270(0)^{\mathrm{z}}$ \\
Late & 225 & $202(10 \%)$ & $74(67 \%)$ \\
\multicolumn{4}{c}{ San Antonio } \\
\hline Season & Avg (mm) & 2007 \\
\hline Early & 187 & $167(11 \%)$ & 2008 \\
Mid & 245 & $557(+127 \%)$ & $238(3 \%)^{\mathrm{y}}$ \\
Late & 179 & $36(80 \%)$ & $23(87 \%)$ \\
\hline${ }^{\mathrm{z}}$ A total of $34 \mathrm{~mm}(50 \%$ of season) in 3 weeks of \\
August. \\
A A total of $104 \mathrm{~mm} \mathrm{(43 \%} \mathrm{of} \mathrm{season)} \mathrm{in} \mathrm{2} \mathrm{weeks} \mathrm{of}$ \\
August.
\end{tabular}

by vacuum. The leachate pipe consisted of three $1.83-\mathrm{m}$ long pieces of $1.27-\mathrm{cm}$ diameter pipe manifolded together at one end and equipped with a $0.76-\mathrm{m}$ tall standpipe as shown in Figure 1. The end of each lateral was permanently capped. In the bottom of each lateral line, 3-mm diameter holes were drilled at $10-\mathrm{cm}$ spacing to allow water to enter the pipes.

After the installation of the leachate lines and gravel layer, soil was added in lifts. The soil was from the A horizon of the Rader fine sandy loam soil series (fine-loamy, mixed, semiactive, thermic Aquic Paleustalfs). All soil was passed through a $1.27-\mathrm{cm}$ diameter screen before placement in the lysimeter. Approximately 15 to $20 \mathrm{~cm}$ of loose soil was added and manually compacted with a hand tamper to a finished depth of $10 \mathrm{~cm}$. The surface of each lift was lightly scarified with a garden rake before adding the next lift of soil. When the soil surface reached 10 to $15 \mathrm{~cm}$ below the top of the lysimeters, a 15 $\mathrm{cm}$ wide strip of $0.1 \mathrm{~mm}$ plastic was taped to the inside of the lysimeter wall using duct tape. This plastic sheet extended $\approx 5 \mathrm{~cm}$ up the lysimeter wall and $10 \mathrm{~cm}$ horizontally toward the center of the lysimeter on top of the compacted lift of soil. The plastic sheet provided a mechanical barrier to reduce the potential for side wall flow and helped force moving water downward and away from the side walls of the lysimeters so that it would flow through the bulk soil (Brown et al., 1985). Additional soil lifts were added until the lysimeters reached capacity. The average soil bulk density at $12 \mathrm{~cm}$ in July 2008 was $1.50 \pm 0.03 \mathrm{Mg} \cdot \mathrm{m}^{-3}$. Lysimeters for the SA location were built in CS, transported to SA, and installed in-ground.

Six soil moisture sensors (ECH2O Probes, Model EC-20; Decagon Devices, Pullman, WA) were placed in two locations $(60 \mathrm{~cm}$ from each end) in each lysimeter (three sensors per location). Sensors monitored volumetric water content at 0 - to 20-, 20- to 40-, and 40- to $60-\mathrm{cm}$ depths (soil surface down to the gravel layer). Cables from the sensors were routed along the inside wall of the lysimeters. All wires were taped to the inside of the lysimeter walls (Fig. 1). From the lysimeters, the cables were enclosed in a $10-\mathrm{cm}$ diameter perforated corrugated drainage pipe and routed to a nearby data collection station. Volumetric soil moisture content measurements were collected using a data logger (model 10X; Campbell Scientific Inc., Logan,
UT) coupled with Model AM 16/32 multiplexers. Measurements were taken every 15 min and averaged for every $30 \mathrm{~min}$. At the CS location, a handheld PDA (Palm; Model $500 \mathrm{~m}$ ) and appropriate software (P Connect, Version 2.0; Campbell Scientific Inc.) was used to manually download data weekly. At the SA location, data collection was accomplished using a Com 210 modem and analog telephone line (Com 210; Campbell Scientific Inc.). This allowed daily transfer of data to a central computer in CS.

Lysimeters at each location were irrigated with a two-zone in-ground automatic system. Irrigation spray heads (Hunter PGJ Series, San Marcos, CA) were installed at 3.65-m triangulated spacing. A water meter was installed in each zone to allow measurement of total applied water.

A weather station was located within 250 $\mathrm{m}$ of the lysimeters at CS and SA. Environmental data included precipitation, radiant energy, wind speed, humidity, and temperature. Data from these stations were used to calculate reference evapotranspiration using the modified Penman-Monteith equation (FAO Irrigation and Drainage Papers-56, 1998). Irrigation was adjusted every 2 to 3 weeks to replace $100 \%$ of calculated reference evapotranspiration minus precipitation. During periods when irrigation water was required, water was applied 1 or $2 \mathrm{~d}$ per week.

Plant treatments. Treatments were arranged in a randomized complete block design with three replications. The plant treatments were randomly assigned to the lysimeters within each block and included: St. Augustinegrass [Stenotaphrum secundatum (Walt.) Kuntze.] $100 \%$ cover, Shumard red oak (Quercus shumardii Buckl.) tree alone with bare soil, native grasses little bluestem [Schizachyrium scoparium (Michx.) Nash] and pink muhlygrass [Muhlenbergia capillaries (Lam.) Trin.], St. Augustinegrass plus one shumard red oak, and native grasses plus one shumard red oak.

Plant installation occurred on 19 Dec. 2006 and 20 Dec. 2006 for the SA and CS locations, respectively. To avoid disturbing sensors and sensor cables, container-grown (11.4 L) shumard red oak trees were planted in the center of the lysimeters. Treatments receiving St. Augustinegrass (All Seasons Turfgrass Inc., Brookshire, TX) were planted with sod grown on a Katy fine-sandy loam series (fine-loamy, siliceous, thermic Aquic Paleudalf). Native grass treatments received nine field-grown (3-L root ball) individual

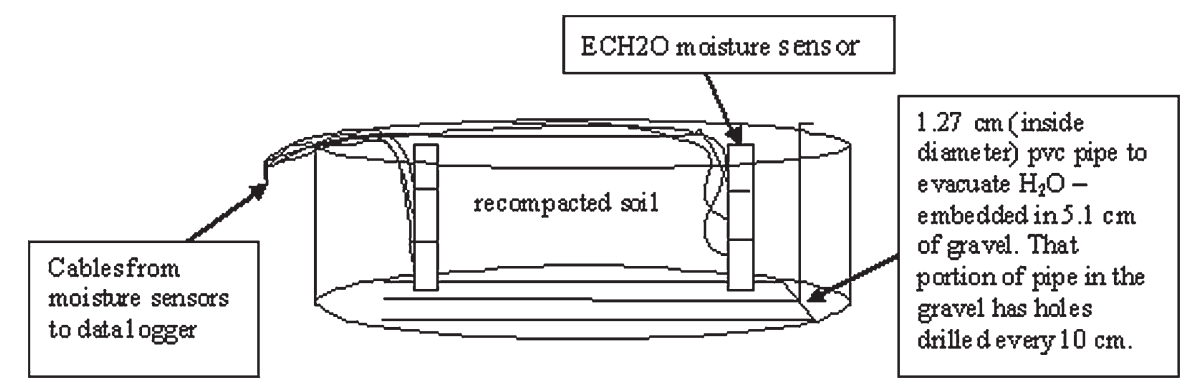

Fig. 1. Schematic drawing of the lysimeter design. 
little bluestem and two container-grown (5.7$\mathrm{L}$ root ball) individual pink muhlygrass. The native grass plus red oak treatment received eight little bluestems and two pink muhlygrass. Native grasses were spaced equidistant across the lysimeter.

Site management. St. Augustinegrass was maintained at 5- to 7.6-cm cutting height with a mowing frequency of every 2 to 4 weeks. Clippings were returned to the plots. The bluestem and muhlygrass (native grass treatment) were trimmed to 15 to $18 \mathrm{~cm}$ each December. The soil in the St. Augustinegrass alone treatment was used as a reference for fertility decisions. The soil in the St. Augustinegrass alone treatment was sampled ( 0 - to $15-\mathrm{cm}$ depth) for laboratory analysis two to three times each year (Soil, Water, and Forage Testing Laboratory, College Station, TX). Phosphorus, potassium, $\mathrm{Ca}, \mathrm{Mg}, \mathrm{Na}$, and sulfur were extracted using the Mehlich III extractant (Mehlich, 1978) and were determined by the inductively coupled plasma method. Based on soil analysis, a balanced fertilizer was added to all treatments during 2007 and 2008. Nitrogen at a rate of 48.8 $\mathrm{kg} \cdot \mathrm{ha}^{-1}$ was applied in three separate events each year. Plant tissue analysis was conducted in July 2008 for the St. Augustinegrass treatment only to evaluate plant health and potential negative effects of soil salts. Lysimeters were evacuated every 2 to 4 weeks to avoid prolonged saturation of the gravel layer.

Landscape coefficient determination. Landscape coefficients were determined from changes in volumetric water content during 2 to $5 \mathrm{~d}$ of soil drying and from $\mathrm{ET}_{\mathrm{o}}$ amounts during the same period. Soil drying periods occurred as a result of lack of precipitation and during intervals between irrigations. Soil drying periods began at $0001 \mathrm{HR}$ 24 to $48 \mathrm{~h}$ after an irrigation or precipitation event and continued until $0001 \mathrm{HR}$ before an irrigation or precipitation event ended the drying period. Changes in soil water volume during soil drying periods provided actual evapotranspiration data for each treatment. Actual evapotranspiration and $\mathrm{ET}_{\mathrm{o}}$ data were used to calculate landscape coefficients by:

$\mathrm{K}_{\mathrm{L}}=$ actual $\mathrm{ET} \div$ reference $\mathrm{ET}$ in which:

$\mathrm{K}_{\mathrm{L}}=$ landscape coefficient
Actual ET = actual evaporation and transpiration water loss

Reference ET = hypothetical evaporation and transpiration water loss as predicted by the modified Penman-Monteith equation.

Observations were grouped into early, mid, and late season (Table 2). Early season was designated as ordinal calendar Days 78 to 153 ( $75 \mathrm{~d})$, midseason as Days 154 to 259 (105 d), and late season as Days 260 to 335 $(75 \mathrm{~d})$. This grouping of dates into three seasons corresponds to patterns of seasonal water deficit as shown in Figure 2, average $\mathrm{ET}_{\mathrm{o}}$ - average rainfall for CS and SA.

Stomatal conductance. A steady-state diffusion porometer (Leaf Porometer, Model SC-1; Decagon Devices Pullman, WA) was used to measure leaf stomatal conductance $\left(g_{\mathrm{S}}\right)$. Every 4 to 6 weeks during active growth, conductance was measured in all treatments near solar noon under non-limiting soil moisture conditions. Three undamaged, recently matured leaves (subsamples) were randomly selected from each treatment block with St. Augustinegrass. The area of the St. Augustinegrass covering the lysimeter was visually divided into three equal areas, and one leaf from each of the three areas was selected for measurement. In treatments with red oak tree, a leaf from the lower, mid, and upper canopy in full sun exposure was used for measurement. The porometer's sensor was placed on the red oak leaf at the first or second lobe behind the apex at a point that would not cover a vein. Soil salinity affects a plant's ability to take up water for transpiration and for other metabolic processes (Munn, 2002). Stomatal conductance data measured in regular intervals during the growing season was a possible indicator of plant stress within species and between sites.

Grass biomass accumulation. In Nov. 2007 and Nov. 2008, the above-ground accumulation of native and turfgrass leaves and stems, both living and in various states of decay, were collected for a season-end grass biomass calculation. In those treatments with St. Augustinegrass and native grasses, a $100-\mathrm{cm}^{2}$ flat, square grid was randomly placed on the lysimeter. Leaves and stems, of the grasses only, in the three-dimensional volume of the square grid were harvested, dried at $105{ }^{\circ} \mathrm{C}$ for $96 \mathrm{~h}$, weighed, and converted to kilograms biomass/ha.

Statistical analysis. Treatment $\mathrm{K}_{\mathrm{L}}$ values by region, biomass accumulation, and $g_{\mathrm{S}}$ were analyzed by using Proc GLM in SAS Version 9.2 (SAS Institute, 2008) for a randomized complete block design with a factorial structure that included plant treatment and seasons. Treatment means were separated by Scheffe's mean separation test. Effects were tested at an alpha level of $P \leq 0.05$. Statistical null hypotheses were as follows: mean $\mathrm{K}_{\mathrm{L}} \mathrm{S}$ were the same by treatment and season for each region; mean grass biomass accumulations were the same by treatment and region; and mean $g_{\mathrm{S}}$ were the same by treatment and region.

\section{Results}

Landscape coefficients in San Antonio. The analysis of variance (ANOVA) model was significant with the source of variation in the main effects of plant treatment $(P<$ $0.0001)$ and season $(P<0.0001)$. During the combined 2007 and 2008 growing seasons, the mean $\mathrm{K}_{\mathrm{L}}$ was greater for native grass, native grass plus tree, and St. Augustinegrass plus tree than for tree alone (Table 3 ). The $\mathrm{K}_{\mathrm{L}}$ for St. Augustinegrass did not differ significantly from the other plant treatments. The overall seasonal $\mathrm{K}_{\mathrm{L}}$ increased from early season through late season by $61 \%$ (Table 3 ). The $\mathrm{K}_{\mathrm{L}}$ for individual plant treatments by season increased from early season to late season.

Landscape coefficients in College Station. The ANOVA model was not significant $(P=0.1078)$ for $\mathrm{K}_{\mathrm{L}}$ for the combined 2007 and 2008 growing seasons. The overall plant treatment $\mathrm{K}_{\mathrm{L}}$ s ranged from 0.21 to 0.34 . The overall seasonal $\mathrm{K}_{\mathrm{L}} \mathrm{S}$ ranged from 0.24 to 0.40. From 1 Mar. to 3 Oct. 2008 in CS, precipitation was $519 \mathrm{~mm}$, and the average rainfall for this time period was $690 \mathrm{~mm}$. The irrigation water used for $100 \%$ replacement of ET loss contributed $\mathrm{Na}$ and bicarbonate at each irrigation resulting in elevated soil $\mathrm{Na}$ in CS. In July 2008 in CS, the soil pH was 8.7 and the $\mathrm{Na}$ concentration was 402 parts per million (ppm).

Stomatal conductance. Mean $g_{\mathrm{S}}$ of the tree was greater in SA than in CS when grown alone and when grown with St. Augustinegrass (Table 4). This suggests that soil $\mathrm{Na}$

Table 2. Calendar dates used for landscape coefficient calculations.

\begin{tabular}{|c|c|}
\hline$\overline{\text { College Station }}$ & San Antonio \\
\hline \multicolumn{2}{|l|}{ Midseason } \\
\hline 8-11, 17-21, 23-24 Oct., 1-4 Nov. & 9-12, 17-19 Oct., 30 Oct. to 4 Nov., $13-16$ Nov. \\
\hline \multicolumn{2}{|c|}{2008} \\
\hline Midseason & \\
\hline $2-5,9-12,16-19,23-26$ June, $21-22,28-31$ July & 3-6, 10-13, 17-20, 24-27 June, 15-18 July, 29 July to 1 Aug., 6-9 Aug. \\
\hline Late season & \\
\hline 23-26 Sept., 30 Sept. to 3 Oct., $12-14,20-23$ Oct. & $16-18,22-25$ Sept., 6-9, 20-22 Oct. \\
\hline
\end{tabular}




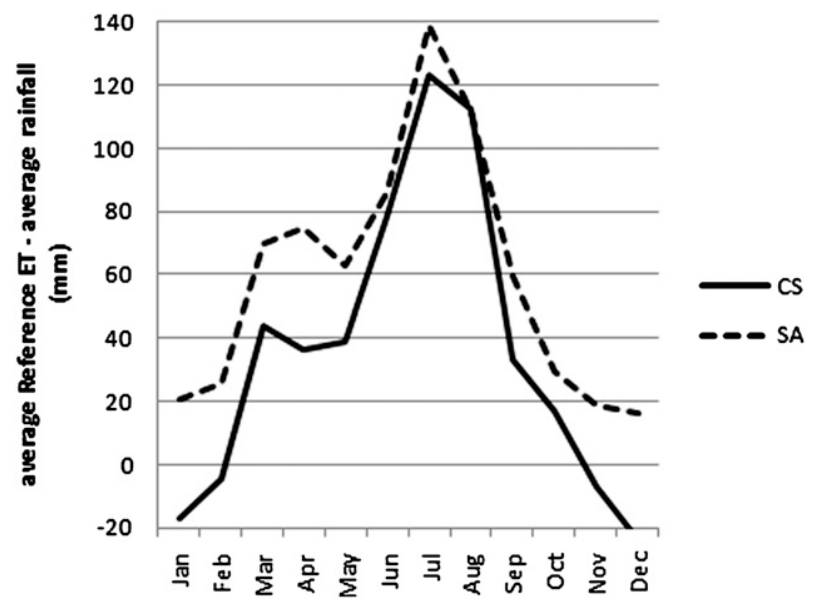

Fig. 2. Historical monthly difference of evapotranspiration $\left(\mathrm{ET}_{\mathrm{o}}\right)$ and rainfall $(\mathrm{mm})$ in College Station and San Antonio, TX.

Table 3. The $\mathrm{K}_{\mathrm{L}}$ for single- and mixed-species plantings by season and location.

\begin{tabular}{|c|c|c|c|c|c|c|}
\hline & \multicolumn{6}{|c|}{$\overline{K_{L}}$} \\
\hline & \multicolumn{3}{|c|}{ San Antonio } & \multicolumn{3}{|c|}{ College Station } \\
\hline St. Augustine & \multicolumn{3}{|c|}{$0.52 a^{z}$} & \multicolumn{3}{|c|}{$0.34 \mathrm{NS}$} \\
\hline St. Augustine + tree & \multicolumn{3}{|c|}{$0.61 \mathrm{a}$} & \multicolumn{3}{|c|}{0.34} \\
\hline Tree & \multicolumn{3}{|c|}{$0.43 \mathrm{~b}$} & \multicolumn{3}{|c|}{0.21} \\
\hline Native grass & \multicolumn{3}{|c|}{$0.61 \mathrm{a}$} & \multicolumn{3}{|c|}{$\begin{array}{l}0.30 \\
0.33\end{array}$} \\
\hline \multirow[t]{2}{*}{ Native + tree } & & $0.61 \mathrm{a}$ & & & 0.33 & \\
\hline & Early & Mid & Late & Early & Mid & Late \\
\hline \multirow[t]{2}{*}{ Seasonal mean } & $0.44 \mathrm{C}^{y}$ & $0.55 \mathrm{~B}$ & $0.71 \mathrm{~A}$ & $0.39 \mathrm{NS}$ & 0.28 & 0.24 \\
\hline & Early & Mid & Late & Early & Mid & Late \\
\hline St. Augustine & $0.45 \mathrm{NS}$ & $0.52 \mathrm{NS}$ & $0.62 \mathrm{NS}$ & $0.51 \mathrm{NS}$ & $0.27 \mathrm{NS}$ & $0.24 \mathrm{NS}$ \\
\hline St. Augustine + tree & 0.56 & 0.56 & 0.72 & 0.47 & 0.32 & 0.23 \\
\hline Tree & 0.31 & 0.37 & 0.66 & 0.24 & 0.19 & 0.20 \\
\hline Native grass & 0.40 & 0.68 & 0.80 & 0.37 & 0.30 & 0.23 \\
\hline Native + tree & 0.48 & 0.62 & 0.75 & 0.40 & 0.29 & 0.31 \\
\hline
\end{tabular}

${ }^{\mathrm{z}}$ Means with the same lower case letter within column are not significantly different under Scheffe's mean separation test at $P \leq 0.05$.

${ }^{y}$ Means with the same upper case letter within row are not significantly different under Scheffe's mean separation test at $P \leq 0.05$.

$\mathrm{NS}=$ nonsignificant.

Table 4. The average stomatal conductance $\left(\mathrm{mol} \cdot \mathrm{m}^{-2} \cdot \mathrm{s}^{-1}\right)$ and SD of tree alone and tree when combined with native grasses and St. Augustine by region.

\begin{tabular}{|c|c|c|c|}
\hline & Tree & $\begin{array}{l}\text { Tree with native } \\
\text { grasses }\end{array}$ & $\begin{array}{c}\text { Tree with } \\
\text { St. Augustine }\end{array}$ \\
\hline$\overline{\text { Region }}$ & & & \\
\hline $\mathrm{CS}$ & $0.225 \pm 0.119 \mathrm{~B}^{\mathrm{z}}$ & $0.240 \pm 0.114 \mathrm{~A}$ & $0.156 \pm 0.069 \mathrm{~B}$ \\
\hline SA & $0.272 \pm 0.114 \mathrm{~A}$ & $0.198 \pm 0.105 \mathrm{~B}$ & $0.195 \pm 0.103 \mathrm{~A}$ \\
\hline
\end{tabular}

${ }^{\mathrm{z}}$ Stomatal conductance means with the same letter within column are not significantly different based on Scheffe's mean separation test.

accumulation in CS limited gas exchange and water use in the tree. However, the mean tree $g_{\mathrm{S}}$ was greater in CS than SA when grown with native grasses (Table 4). The mean tree alone $\mathrm{K}_{\mathrm{L}}$ during the entire study was 0.43 for SA and 0.21 for CS.

The $g_{\mathrm{S}}$ of the St. Augustinegrass was the same regardless of the region or the presence of a tree. Mean $g_{\mathrm{S}}$ of the St. Augustinegrass during the entire study ranged from $0.056 \pm$ 0.037 to $0.067 \pm 0.047 \mathrm{~mol} \cdot \mathrm{m}^{-2} \cdot \mathrm{s}^{-1}$. Mean $g_{\mathrm{S}}$ of the native grass is not presented as a result of lack of confidence in the data of the pink muhlygrass.

Grass biomass accumulation. Grass biomass accumulation was determined by random placement of grids in lysimeters with St. mean overall $\mathrm{K}_{\mathrm{L}}$ by region for this study was 0.61 and 0.34 for SA and CS, respectively.

\section{Discussion}

Water use of turfgrass increases in the fall typically displaying seasonality. Brown et al. (2001) reported that bermudagrass water use increased from June to September. Carrow (1995) also found that after averaging the water consumption from two growing seasons that 'Raleigh' St. Augustinegrass had greater water use in September and October than in July and August. In our study, St. Augustinegrass $\mathrm{K}_{\mathrm{L}}$ increased seasonally in $\mathrm{SA}$. The untrimmed native grasses increased in height and girth from spring until the first frost in November, whereas the mowed St. Augustinegrass had a relatively constant plant height and density during this time period. The native grasses with a more three-dimensional canopy thus have higher boundary layer resistance and therefore higher conductance. Plant canopy dimensions may have contributed to the seasonal differences in $\mathrm{K}_{\mathrm{L}}$ in SA between the low-growing turfgrass and the upright bunchgrass-type growth of the native grass. However, during the study, the mean $\mathrm{K}_{\mathrm{L}}$ for native grass was not statistically different from the $K_{L}$ of St. Augustinegrass with or without a tree. This would imply that a seasonal $\mathrm{K}_{\mathrm{L}}$ could be used in irrigation recommendations for amenity landscapes with mixed species.

Irrigation of turfgrass with water high in Na may be inducing sodic soil conditions (e.g., Aitkenhead-Peterson et al., 2009). Irrigation water, rather than precipitation, became a larger component of $\mathrm{ET}_{\mathrm{o}}$ replacement in late spring and summer (Table 1). Irrigation water quality may have influenced $\mathrm{K}_{\mathrm{L}}$. CS irrigation water $(\mathrm{SAR}=38)$ was high in $\mathrm{Na}$ and bicarbonate and is assessed as a $\mathrm{Na}-\mathrm{HCO}_{3}{ }^{-}$ water, whereas SA irrigation water $(\mathrm{SAR}=$ $0.5)$ was high in $\mathrm{Ca}$ and carbonate and is assessed as $\mathrm{Mg}-\mathrm{HCO}_{3}{ }^{-}$water. The effects of soil $\mathrm{Na}$ on landscape plant performance in $\mathrm{CS}$ are evidenced in the greater $\mathrm{K}_{\mathrm{L}}$ and biomass accumulation in the SA region. Na accumulation in CS likely altered soil water potential and may have caused reduced evapotranspiration compared with SA. Leaf margin necrosis in the Shumard red oak trees in CS was observed initially in early July 2008, and this condition continued into October (data not presented). This marginal leaf necrosis appeared symmetrical, indicating a visual symptom of salt stress (Hammerschlag et al., 1986).

The decreasing $K_{L}$ values with season in $\mathrm{CS}$ may be the result of the effects of $\mathrm{Na}$ in the soil and plant tissue. Tissue analysis from the St. Augustinegrass treatment was 11,362 ppm $\mathrm{Na}$ in CS compared with 7,882 ppm from SA. Soil and plant tissue $\mathrm{Na}$ content may have affected the plant's ability to take up water for transpiration and other metabolic processes (Ben-gal and Shani, 2002; Munn, 2002). Furthermore, the average leachate volume per treatment was $85.8 \mathrm{~L}$ in SA and $131.1 \mathrm{~L}$ in CS representing 53\% more leachate from the CS site although 
irrigation was at $100 \%$ replacement of $\mathrm{ET}_{\mathrm{o}}$ losses at both sites. This is a further indication of reduced water use in CS.

High soil Na generally reduces plant transpiration and biomass accumulation in landscape vegetation (e.g., Eom et al., 2007; Sagi et al., 1998). Eom et al. (2007) found differential responses of six herbaceous perennials to soil $\mathrm{Na}$ concentrations, transpiration, and reduced biomass. In general, increasing soil $\mathrm{Na}$ concentrations reduced transpiration and biomass accumulation for the six ground covers. Increasing soil $\mathrm{Na}$ concentration also lowered biomass accumulation in annual ryegrass (Lolium multiflorum Lam.) grown in sand (Sagi et al., 1998). The overall grass biomass accumulation in CS may have also been affected by the presence of high soil $\mathrm{Na}$ concentrations (402 ppm Na in July 2008) compared with our site at SA. Stomatal conductance values were not necessarily reflective of seasonal or regional water use. Most of the species-to-species $g_{\mathrm{S}}$ comparisons were generally larger in SA. Potentially this was caused by a greater $\mathrm{ET}_{\mathrm{o}}$ in $\mathrm{SA}$ and/or a soil $\mathrm{Na}$ induced osmotic factor in water potential in $\mathrm{CS}$. It is possible that the soil $\mathrm{Na}$ concentration in CS reduced the $g_{\mathrm{S}}$ as well as the water use.

Seasonal differences in plant treatment $\mathrm{K}_{\mathrm{L}} \mathrm{S}$ were much larger in SA than the $K_{L} S$ in CS. The increase in $\mathrm{K}_{\mathrm{L}}$ from early to midseason in the plant treatments in SA followed a corresponding increase in evaporative demand during this time period. Evidence now exists to use $\mathrm{ET}_{\mathrm{o}}$ data as a predictor of seasonal water demand in mixed-species landscapes. Also, the negative influence of soil $\mathrm{Na}$ accumulation on plant water use is demonstrated.

The literature includes several examples of crop coefficients for turfgrass as a single species (Brown et al., 2001; Carrow, 1995; Ervin and Koski, 1998; Kim and Beard, 1988) and for woody plants as a single species (Levitt et al., 1995; Maupin and Struve, 1997) but very few examples for mixed-species plantings. White et al. (2004) described the potential for water savings in mixed-species landscapes by using a coefficient of 0.7 . However, that study did not include field data measurements of actual water use. There is a lack of sciencebased information on seasonal irrigation coefficients for mixed-species landscapes. The results of this study trend toward acceptable irrigation coefficients of $0.5,0.6$, and 0.7 (early, mid, and late season, respectively) in non-sodic mixed-species landscape sites. St. Augustinegrass is widely used in the southern United States in mixed-species landscapes (Saha et al., 2007). This same seasonal $\mathrm{K}_{\mathrm{L}}$ recommendation of $0.5,0.6$, and 0.7 may also be acceptable at landscape sites irrigated with sodic water to promote leaching of $\mathrm{Na}$. This of course should be coupled with other remediation techniques such as gypsum applications. More work in landscape coefficients is needed. New studies should include other climatic regions and use of other woody plant species combinations. Corresponding work should also determine the aesthetic acceptability of the landscape plants grown under a landscape coefficient less than 1.0
Municipalities and water planning agencies use several methods to promote water conservation among users (Barta, 2004; Desena, 1998; Vickers, 2001; Water Information, 2006). The use of a landscape coefficient for irrigating mixed-species landscapes has potential to be used in planning regional water needs. Seasonal landscape water demand could be closely predicted with a landscape coefficient, weather station data, and number of irrigated acres in the region.

The native grasses potentially have higher landscape coefficients than the turfgrass or tree alone. It appears the native grasses are opportunistic plants in regard to water use. Further study on the native grasses water use might determine if lower seasonal $\mathrm{K}_{\mathrm{L}} \mathrm{s}$ (e.g., $0.5)$ are acceptable for growth and maintenance that meets a specific aesthetic level in the landscape.

\section{Literature Cited}

Aitkenhead-Peterson, J.A., M.K. Steele, N. Nahar, and K. Santhy. 2009. Dissolved organic carbon and nitrogen in urban and rural watersheds of south-central Texas: Lands use and land management influences. Biogeochemistry 96:119129.

Barta, R. 2004. Stretching urban water supplies in Colorado: Strategies for landscape water conservation. Colorado Water Resources Research Institute, Special Report No. 13.

Beard, J.B. and R.L. Green. 1994. The role of turfgrasses in environmental protection and their benefits to humans. J. Environ. Qual. 23:452-460.

Ben-gal, A. and U. Shani. 2002. Yield, transpiration and growth of tomatoes under combined excess boron and salinity stress. Plant Soil 247: 211-221.

Brown, K.W., J.C. Thomas, and M.W. Aurelius. 1985. Collecting and testing barrel sized undisturbed soil monoliths. Soil Sci. Soc. Amer. J. 49:1067-1068.

Brown, P.W., C.F. Mancino, M.H. Young, T.L. Thompson, P.J. Wierenga, and D.M. Kopec. 2001. Penman Monteith crop coefficients for use with desert turf systems. Crop Sci. 41: 1197-1206.

Carrow, R. 1995. Drought resistance aspects of turfgrasses in the southeast: Evapotranspiration and crop coefficients. Crop Sci. 35:1685-1690.

Carrow, R.N. and R.R. Duncan. 1998. Salt affected turfgrass sites: Assessment and management. Ann Arbor Press, Chelsea, MI

Dean, D.E., D.A. Devitt, L.S. Verchick, and R.L. Morris. 1996. Turfgrass quality, growth, and water use influenced by salinity and water stress. Agron. J. 88:844-849.

Desena, M. 1998. Irvine Ranch Water District uses rate structures to spur conservation. U.S. Water News 15:1-3.

Eom, S.H., T.L. Setter, A. DiTommaso, and L.A. Weston. 2007. Differential growth response to salt stress among selected ornamentals. J. Plant Nutr. 30:1109-1126.

Ervin, E.H. and A.J. Koski. 1998. Drought avoidance aspects and crop coefficients of kentucky bluegrass and tall fescue in the semiarid west. Crop Sci. 38:788-795.

FAO Irrigation and Drainage Papers-56. 1998. The Food and Agriculture Organization web site. 27 Feb. 2009. <http://www.fao.org/docrep/ X0490E/x0490e06.htm>.

Hammerschlag, R., J. Sherald, and S. Kostka. 1986. Shade tree leaf scorch. J. Arboriculture 12:38-43.
Kim, K. and J. Beard. 1988. Comparative turfgrass evapotranspiration rates and associated plant morphological characteristics. Crop Sci. 28:328 331.

Kjelgren, R., L. Rupp, and D. Kilgren. 2000. Water conservation in urban landscapes. HortScience 35:1037-1040.

Levitt, D.G., J.R. Simpson, and J.L. Tipton. 1995 Water use of two landscape tree species in Tucson, Arizona. J. Amer. Soc. Hort. Sci. 120: 409-416.

Maupin, C. and D.K. Struve. 1997. Red oak transplanted to different bulk density soils have similar water use characteristics. J. Arboriculture 23:233-237.

McCready, M.S., G.L. Miller, and M.D. Dukes. 2009. Water conservation potential of smart irrigation controllers on St. Augustinegrass. Agr. Water Manage. 96:1623-1632.

Mehlich, A. 1978. New extractant for soil test evaluation of phosphorus, potassium, magnesium, calcium, sodium, manganese, and zinc. Commun. Soil Sci. Plant Anal. 9:477-492.

Munn, R. 2002. Comparative physiology of salt and water stress. Plant Cell Environ. 25:239250 .

Peterson, K.A., L.B. McDowell, and C.A. Martin 1999. Plant life form frequency, diversity, and irrigation application in urban residential landscapes. HortScience 34:491.

Sagi, M., A. Dovrat, T. Kipnis, and H. Lips. 1998. Nitrate reductase, phosphoenolpyruvate carboxylase, and glutamine synthetase in annual ryegrass as affected by salinity and nitrogen. J. Plant Nutr. 21:707-723.

Saha, S., L.E. Trenholm, and J.B. Unruh. 2007. Effect of fertilizer source on nitrate leaching and St. Augustinegrass turfgrass quality. HortScience 42:1478

SAS Institute. 2008. SAS user's guide: Statistics, SAS system. Version 9. SAS Inst., Cary, NC.

Shaw, D.A. and D.R. Pitttenger. 2004. Performance of landscape ornamentals given irrigation treatments based on reference evapotranspiration. Acta Hort. 664:607-614.

Texas Water Development Board. 2003. 2003 Water use survey summary estimates. TWDB, Austin, TX. 5 Oct. 2009. <http://www.twdb.state. tx.us/data/popwaterdemand/2003Projections/ HistoricalWaterUse.asp $>$.

Texas Water Development Board. 2007. 2007 State water plan. TWDB, Austin, TX. 5 Oct. 2009. $<\mathrm{http}$ ://rio.twdb.state.tx.us/publications/reports/ State_Water_Plan/2007/2007StateWaterPlan/ Chapter04.pdf $>$.

U.S. Geologic Survey. 2006. Water science for schools. 6 May 2007. <http://ga.water.usgs. gov/edu/earthwherewater.html>.

Vickers, A. 2001. Water use \& conservation. WaterPlow Press, Amherst, MA.

Wang, Y. and N. Nii. 2000. Changes in chlorophyll, ribulose bisphosphate carboxylase-oxygenase, glycine betaine content, photosynthesis and transpiration in Amaranthus tricolor leaves during salt stress. J. Hort. Sci. Biotechnol. 75:623-627.

Water Information. 2006. Albuquerque official city web site. 27 June 2006. <http://www.cabq.gov/ waterconservation/index.html>

Welsh, D., W. Welch, and R. Duble. 2000. Landscape water conservation. Texas A\&M University, 5 Oct. 2009. <http://aggie-horticulture. tamu.edu/extension/xeriscape/xeriscape.html $>$.

White, R., R. Havlak, J. Nations, T. Pannkuk, J. Thomas, D. Chalmers, and D. Dewey. 2004. How much water is 'enough'? Using PET to develop water budgets for residential landscapes. TX Water Resources Institute TR-271. College Station, TX. 